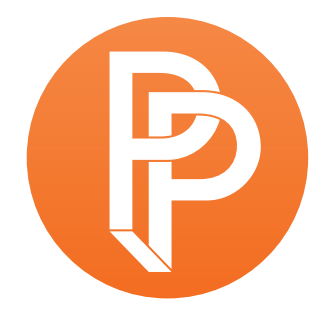

PERFORMANCE

PHILOSOPHY

\title{
CAESURA OF HISTORY: PERFORMING GREEK TRAGEDY AFTER BRECHT
}

\author{
MATTHIAS DREYER GOETHE-UNIVERSITY FRANKFURT
}

While for centuries Greek tragedies were performed only intermittently (Flashar 1991; Foley 1999; Macintosh et al. 2005; Hall and Macintosh 2005), the 1960s saw an enormous growth internationally in the staging of ancient dramas, and between 1960 and today, more Greek tragedies have been performed than in the entire period from antiquity to $1960 .^{1}$ The new interest in ancient tragedy corresponded with a fundamental crisis in Western culture, issuing from the Shoah and gradually forcing its way into consciousness. After World War II, and especially since the 1960s, the question of history needed to be reconsidered. With the increasing dissolution of tradition, the interval between antiquity and the present became an unresolved problem. At the same time, a teleological understanding, which sees history as something that can be planned and calculated, had to be considered as failed, since fascism and communism 'in the name of history' had erected totalitarian systems. What then appeared in this historical void?

That the question of history is posed in the theatre is not self-evident. However, in the twentieth century, a renewed engagement with ancient Greek tragedy was crucial for the emergence of this question, and can be seen as a challenge for the concept of historicity. And regarding the numerous offers of dealing with the 'challenge of antiquity', it was particularly in the epic theatre that the question of historicity was posed-that is, in a field of influence and contest that extended, via Friedrich Hölderlin, to Walter Benjamin and Bertolt Brecht, and from here to the present. It is therefore worth considering the relationship between epic theatre and ancient Greek tragedy in more detail. Here, the gap between antiquity and the present is not smoothed over, as is the case when the original is simply 'updated', modernised or rendered topical; rather, a 'non- 
contemporaneity' comes into play, one that can be felt in the confrontation with the alterity of antiquity. At stake here are not only specific modern interpretations of ancient drama, but also theoretical and aesthetic questions: how can one think the relation between theatre-which was long seen as an art of the present, or even of presence-and ideas of historical time? How do historical time and historical practices become part of the performance? And to what extent does the performance reveal itself as part of history?

To answer these questions, one must first recall the concept of time and history that the epic theatre attempted to interrupt. This is the idea of making-present (Vergegenwärtigung) that understands the performing of ancient Greek tragedy as the production of an overarching temporality in which universal and timeless truths are supposedly made manifest (discussed further in part 1 below). I would like to call to mind how difficult any departure from this concept is, as it has dominated the discourse on performing ancient Greek tragedy, at least since historicism, and has become-in its mixture of presence and myth-a sort of Leitkultur of classical theatre. In what follows, I shall analyse its temporal implications through a brief discussion of two staging traditions, the historicist and the vitalist, as well as through a reference to the historical hermeneutics of Hans-Georg Gadamer. The critique of this concept is the basis for the concept of 'tragedy as caesura' formulated in the writings on tragedy of Hölderlin and Benjamin, which, after Brecht's Antigonemodell (1948), has also become part of the theatre from a practical-experimental point of view. I shall argue that this concept can be considered as the determining background against which Brecht's understanding of tragedy develops, and which continues to be in effect in ongoing attempts to deal with tragedy today.

Contrary to this, in the concept of the 'tragedy of the caesura', a critical theatre can only grow out of the ruptures between past and present (see part 2). I shall trace what this concept of 'tragedy as caesura' means for the work on ancient tragedy in the theatre (see part 3). Crucial in this context is Brecht's work on Sophocles' Antigone, which he developed in Swiss exile in 1948, and which raises the question of whether historicisation is a fruitful practice for a political theatre (see 3.1). From here, the conditions for a critical concept of history in the theatre emerge, which uncovers historical continuities by questioning the extent to which they can be attacked or changed. Consequently, Brecht's disciples could not adopt his concepts unquestioningly. Instead, they examine aspects that Brecht with his rationalistic approach underestimates; and in doing so they drew on tragedy as a primary material. From the mid-1980s to his death in 2001, the East-German-born theatre maker Einar Schleef used ancient Greek tragedy to reflect on the history of the collective by exploring the aporias of the ancient chorus on stage (see 3.2). Elsewhere, the Bulgarian director Dimiter Gotscheff (1943-2013) considered his numerous stagings of classical drama as scenic experiments to work on techniques of estrangement (Verfremdung). In this way, he was able to explore the mediality of language and the body in order to transform tragedy into an endgame of history (see 3.3). In these works, the question of the caesura in tragedy, which in both Schleef and Gotscheff can be considered as a continuation of a Brechtian approach, is clearly altered. While in Brecht's thought, the caesura was still partly linked to teleology, in the work of Schleef and Gotscheff, it refers to what is repressed in (epic) tradition and in constructions of a homogenous history. 
If one concerns oneself with questions of historicity and attempts to make a critical theatre with ancient tragedy, a problem one immediately faces is the legacy of associating ancient tragedy with claims to the universal and timeless. In this connection, one should recall two points of departure at the beginning of modern theatre-both of which are still prevalent today. The first is the historicist approach, which aims to frame the staging of ancient drama as an educational journey to the past. The most important early example of this tendency took place in Germany in 1841. This was the famous staging of Antigone in Potsdam in a scenic arrangement by Ludwig Tieck and with a stage composition by Felix Mendelssohn. The only previous performance of Antigone in German was in 1804 by Goethe at the Hoftheater in Weimar in a contemporary adaptation by Johann Friedrich Rochlitz; Hölderlin's remarkable translation from 1804 was rejected by theatre makers during his lifetime, and was not performed until 1919. The Potsdam Antigone from 1848 was the first staging to make use of a faithful and unabridged translation of the ancient text. With the help of the most important classical scholars of the time, the aim was to recreate 'authentic' performance conditions (on this staging, see Flashar 1991; Boetius 2005; Stenzel 2009). In this sense, in the spirit of historicism, the adaptation was understood as objective-and, as sources of the time show, this was associated with 'general, eternal truths'. The historian Johann Gustav Droysen for example praised the staging for bringing to light the 'great and immortal' of the past (quoted in Fischer-Lichte 1998, 114).

Such general claims are also made by the discourses and stagings of the second tendency, which also aims at the timeless and universal. I call this the vitalist tendency; its goal is to radically transport the ancient drama into the present of the performance. One of the founding fathers of this tendency was Max Reinhardt, who announced his emphatic vision in 1901. According to Reinhardt, 'One has to perform the classics [...] as if they were poets of today, their works lives of today' (Reinhardt [1901] 1974, 66). Reinhardt staged the tragedies Oedipus (1910) and The Oresteia (1911 and 1919) in Berlin and Munich, and, with his forceful mass choruses, established an archaic style that sought to overpower the senses.

In the intoxicating experience of the theatre, the construction of history remains unreflected. ${ }^{2}$ Accordingly, both approaches-historicist and vitalist-sought to harmonise the horizons of the past and the present in order to celebrate a claim to the universally human in the classical works. Walter Benjamin responded to this ironically by describing it as a romantic 'hunt for false riches' (Benjamin 1991, 581), an assimilation of the past that does not lead to critical historical work.

This popular claim to the universal and timeless, which is still prevalent in the modern theatre world, can also be observed in the more elaborated ideas of philosophical hermeneutics that attempt to conceptualise the problem of confronting temporal distances. In his major work Truth and Method (1960), Hans-Georg Gadamer underlines how, as an essential condition of understanding, the individual interpreter must first of all distance him- or herself from the present: 
The hermeneutic task consists in not covering up this tension [between the past object and the present position] by attempting a naive assimilation of the two but in consciously enforcing it. This is why it is part of the hermeneutic approach to project a historical horizon that is different from the horizon of the present. (Gadamer [1960] 2006, 305)

On the one hand, this foreign horizon helps one to relativise one's own time. To 'think historicity' means in this sense to overcome the time-bound and allow oneself to be questioned through the horizon of the other. On the other hand, it gives rise to the question of the extent to which it is possible with Gadamerian hermeneutics to encounter this 'other' (for instance, in the form of historically distant theatre concepts or texts) in its foreignness or to preserve its singularity. This question is important because the hermeneutic process, according to Gadamer, should be understood as a 'fusion of these horizons supposedly existing by themselves' (305, my emphasis):

\section{When our historical consciousness transposes itself into historical horizons, this does not entail passing into alien worlds unconnected in any way with our own; instead they together constitute the one great horizon that moves from within and that, beyond the frontiers of the present, embraces the historical depths of our self-consciousness. (303)}

This constantly shifting fusing of horizons brings about 'the rising to a higher universality'. According to such an argument, the fusing of the horizons under the sign of the classical works should yield a truth. It is due to the 'presiding of tradition', in which 'old and new repeatedly come together in a living validity' (305). Hence, this phenomenological fusing of subject and object is in tension with a critical thinking of historical distance. Thus, with regard to current engagements with classical dramas, some observations must be made.

Gadamer overlooks what Foucault would describe soon afterwards as the struggle over historically marked concepts, rules and institutions: that each effective history must also be understood as a history of specific interests and ideologies. Foucault considers any attempt to conceive history as a process of recognition, identity and truth as misguided. Instead of reflecting on the legacies and affiliations with which a claim to unity and coherence was traditionally asserted, historical work, according to Foucault, should shake secure foundations and uncover heterogeneous identities. Furthermore, historical work is significant if it 'places within a process of development everything considered immortal in man' (Foucault 1984, 87). In Gadamer's theory, however, the possibility of a critical distance to tradition is hardly thought, a point that Gadamer partially concedes in a moment of self-criticism: 'Here constantly arises the danger of "appropriating" the other in one's own understanding and thereby failing to recognize his or her otherness' (Gadamer [1960] 2006, 305). These weak points of traditional hermeneutics make it necessary to (re-)consider different dramaturgical and temporal concepts when working on ancient Greek tragedy. 


\section{2) Tragedy and Caesura (Hölderlin, Benjamin)}

Of central importance in this context are the theatre projects that begin by doubting whether Greek tragedy in the modern period can be integrated into the horizon of the present, or, indeed, whether it can even be staged at all. This history of the unstageability of ancient tragedy is, in my view, more instructive than any account of a successful staging. In the former case, attention is shifted to aspects of ancient theatre and Greek tragedy that cannot be accommodated into bourgeois theatre, and have therefore been forgotten or rejected: aspects such as the chorus, the lack of psychological interiority and the dimension of violence in ancient tragedy. ${ }^{3}$

By thinking aspects of the past that could not be realised in history, modern work on ancient tragedy opens up references to the unrealised possibilities of the past. For thinking this theoretically, Benjamin's understanding of history-the idea that contemporaneity can only be opened up through a certain kind of historical work-is central. Only where the linear course of time is burst open and interrupted can history and the present appear as reciprocal processes. In this sense, one's own time should be thought as a moment that is not causally determined by the past, 'but in which time [...] has come to a standstill' (Benjamin [1940] 2003, 396). Accordingly, the horizons of the past and present cannot be reconciled. The present, which according to Benjamin is won from this historical work, is not a self-contained presence; rather, the creation of a historical constellation brings about a split in the present-it creates a 'now-time' (Jetztzeit), which opens itself to an other.

From this point of view, ancient tragedy is particularly well suited to reflect on the modern concept of history as an interruption in the continuum. Indeed, tragedy itself has frequently been described as an interruption: of the ruling powers of fate, of the dramatic development, or even of the aesthetic. This point of view has existed especially since Hölderlin's thoughts on the 'caesura' in tragedy, which he published in 1804 in his remarks on Antigone and Oedipus that appeared alongside his translations of these works. His remarks on the caesura initially refer to what he calls 'tragic transport', the flow between speech and counter-speech. This makes a rupture necessary:

\footnotetext{
Thereby, in the rhythmic sequence of the representations wherein transport presents itself, there becomes necessary what in poetic meter is called caesura, the pure word, the counter-rhythmic rupture; namely, in order to meet the onrushing change of representations at its highest point in such a manner that very soon there does not appear the change of representation but the representation itself. (Hölderlin [1804] 1998a, 102; Hölderlin [1804] 1999a, 250)
}

The caesura is first of all a poetic category. Unlike the constant rhythm of a forward movement leading to a goal, the caesura gives rise to a discontinuity. It explodes the 'onrushing change of representations' and opens up the representation beyond the regular and the calculable. ${ }^{4}$

But what does Hölderlin mean when he writes, 'there does not appear the change of representation but the representation itself'? In order to answer this question, it is necessary first of all to consider the epistemic dimension of tragedy. In tragedy, man is made to confront the limits 
of his agency. Oedipus, for example, is made to experience great suffering because he disregards the limits of his knowledge and attempts to become an equal of God-even to become a god himself. This false fusion of the human and the divine, which Hölderlin interprets as the 'hubris of immediacy', is suspended in the tragic process insofar as man is made to encounter mediacy. This is carried out through the 'pure word', through a language that is pure to the extent that it represents nothing-for instance, through the lament that cannot adequately express pain, but which can be considered as a sign of this inexpressibility.

At the same time, this tragic disturbance is more than a rupture. Hölderlin understands it as a 'reversal of all modes and forms of representation' (Hölderlin 1988b, 114; Hölderlin 1999b, 419). Rather than pointing to a determinable goal, however, this reversal produces a new temporality, one in which-according to Hölderlin's elegant formulation-'beginning and end can simply no longer rhyme with each other' (Hölderlin 1998a, 108; 'Anfang und Ende sich [...] schlechterdings nicht reimen läßt', Hölderlin 1999b, 258). Hence, man 'can no longer place himself in the transition between past and future' (Lemke 2002, 65).

In this sense, the reversal carried out in tragedy is not a realisation of something new; rather, it is characterised by a double reference that, as Samuel Weber (2016) has shown, becomes visible as the 'counter-'. The caesura as a 'counter-rhythmic rupture' does not simply carry out a disengagement; it becomes operative only through the reference to what it wants to interrupt. In the case of Oedipus, this rupture-according to Hölderlin's dramaturgical analysis-is brought about through Tiresias, who tells the tyrant about his mythic prehistory. Hence, the caesura turns simultaneously towards and away from the curse-that is, it recalls the mythical boundedness that reveals to man his limits, and it allows him to think critically about the consequences.

In this article, there is not room to provide a detailed analysis of how Benjamin took up Hölderlin's concept of the caesura. I shall therefore limit myself to a brief mention of his essay Goethe's Elective Affinities (1919-1922), with which Benjamin opposes the 'ideology' of an artwork that 'brings forth a world from nothingness' (Benjamin 2003, 340). Drawing on Hölderlin's idea of the 'pure word', Benjamin develops the idea of an 'expressionless violence' that subverts the 'false, errant totality' of the artwork. Something similar is found in his considerations on tragedy in Ursprung des deutschen Trauerspiels (The Origin of German Tragic Drama), published in 1925, in which Benjamin notes a difference between the continuous cyclical time of myth and the interrupting power of tragedy. Benjamin sums up his considerations on ancient tragedy (which he later confronts with the modern mourning play) as follows: 'It was not in law but in tragedy that the head of genius lifted itself for the first time from the mist of guilt, for in tragedy demonic fate is breached" (Benjamin 2003 , 203). In tragedy, myth is represented, or better repeated; within this repetition, however, a difference arises, so that tragic drama is simultaneously both representation and revision. As a result, tragedy is no longer associated with the universal and timeless, but becomes part of an open historical process, and, furthermore, questions the possibility of historicity. 


\section{3) Caesura in Theatre}

In this way, the conditions are named with which ancient tragedy contests a world of fateful violence and articulates itself as an interface in the transition between times, while simultaneously reflecting on this historical caesura. Hence, the analyses of the tragic and tragedy in Hölderlin and Benjamin address a demand to modern adaptations of ancient tragedy as well as to theatre in general. In this sense, theatre can be thought as a site of encounter with the persisting powers of the past, as their repetition, exposition and suspension. Here, presence in the theatre is understood as a becoming-conscious of historicity and as an interrogation of the caesura with regard to its possibilities and modes of operation. Accordingly, ancient tragedy brings to the fore a reflexive rupture in the transition between times. At the same time, thinking about tragedy implies that this procedure is not to be understood as an empowerment of a new world or a new life over the supposedly 'old', but as an insight into self-restraint, as a limit experience, and as a search for what a different language of the theatre, of thought, of humanity could be. By analysing Brecht's way of working on ancient Greek tragedy as well as the performances of critical theatre makers that came after Brecht, I shall show in the following the consequences of this concept of tragedy on the level of the aesthetics of the theatre.

\section{1) Failure of Historicisation (Brecht)}

Bertolt Brecht's work on ancient Greek tragedy began in 1948 when he returned from exile before founding his own theatre in Berlin, the later Berliner Ensemble. For Brecht, the war left not only the theatre buildings damaged, but also the style of acting. What was missing was a new theatre, which after the rigorous studies and theoretical work of his fifteen years in exile should now be tested and developed in practice. In this period of historical transformation, Brecht drew on Hölderlin's translation of Sophocles' Antigone. His staging of this material took place in 1948 in the Swiss city of Chur, where he was waiting to be able to travel to Berlin.

With this project on ancient drama Brecht was working on a theatre of caesura in the sense discussed above. This is obvious not only by the particular mode of rupture or estrangement he makes use of here, but also by the trans-historical continuities he makes us aware of. This becomes clear in Brecht's way of using the ancient texts-and the contrast to his early notion of 'material value' (Materialwert). In the 1920s, Brecht experimented with classical works, and thereby cultivated the discourse of their material value: one should cannibalise (ausschlachten) historical texts like old cars to see what can still be put to use for the construction of a new art and society (Brecht 1992, 21:164). With the emergence of fascism, his dramaturgy undergoes a clear transformation. He now focuses on the constraints complicating the possibility of change. In Brecht's Hegelian formulation: 'It is recognised that one cannot simply leap over earlier phases [...]. The new exists, but it is only born out of the struggle with the old, not without it, not in a void' (Brecht 1992, 22.1:488-489; the quote comes from notes that were presumably written in 1938). Tragedy is the place in which Brecht's Marxist belief that the world can be changed is challenged.

In his dramaturgical treatment of Antigone, Brecht changed the source of motivation and removed all elements that allowed the action to appear as destiny or fate. According to his basic principle, 
'Man's fate is man' (Brecht 1968, 15:259). The gods have been replaced by socioeconomic conditions that can be criticised and changed: Creon wages war to attain material resources; Polynices is suspected of desertion and killed by Creon; Creon, who is also addressed as Führer, attempts finally to maintain his rule by terror until the whole of Thebes is destroyed.

In all this, there are clear analogies to the Nazi period, whereby Brecht makes the action applicable to the situation of the time. Interestingly, however, he understood 'analogies to the present' as being 'generally disadvantageous' (Brecht 1968, 15:75). Antigone, 'the great figure of resistance in the ancient drama[,] does not represent the fighters of the German resistance' (Brecht 1968, 15:75); she is not glorified as a resistance fighter, since at the beginning she was herself part of the apparatus of power. For Brecht, in order to emphasize the historical distance, the ancient drama should remain sufficiently archaic. In this way, he manifested his rejection of the Aristotelian identification with the protagonist. The actors wore stylised costumes and masklike makeup. When not performing, they sat on long benches at the back of the stage. The brightly lit performance area situated in the front part of the stage was demarcated by four tall posts surmounted with horse skulls. This was meant to indicate that the 'barbarism' of the ancient order had not yet been overcome: 'The performance was situated between the posts because we are still living with the idolatrous state of class struggle!' (Brecht 1992, 25:78).

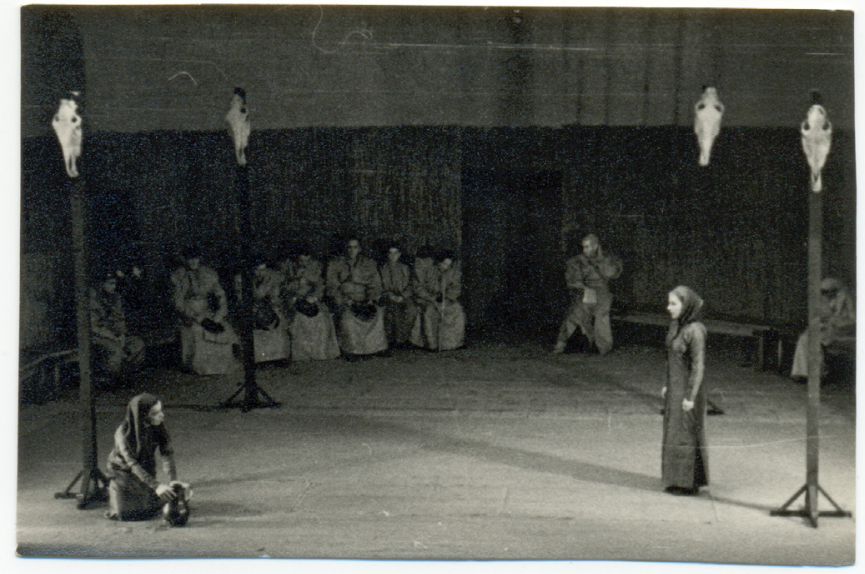

Figure 1: Photo: Ruth Berlau / (c) Hilda Hoffmann

In Horkheimer and Adorno's Dialectic of Enlightenment, too, 'barbarism' is a counter-term for civilisation (Horkheimer and Adorno [1944] 2002, XIV), describing any society for as a long as it accepts human sacrifice as a political means. Brecht's project of historicisation asks how it might be possible to be rid of this cult. Because he could not discern the extent to which ancient tragedy itself undertook a questioning of cultic compulsions-Benjamin talks about a 'revision'-Brecht's intention with Antigone was to show that the play belongs to a time that is still our own, but which should have been surpassed. He thereby historicises both ancient tragedy and the present. By rejecting the fatalism he saw in tragedy, his project pursued a conceptual direction that had already been outlined by Hölderlin and Benjamin concerning the question of the interruption of the continuous time of myth.

If one looks at the press response to Brecht's 1948 staging of Antigone, one notices how few of Brecht's intentions were understood by the critics. Nevertheless, there are clear signs that the analogy between barbaric antiquity and the present was decoded. One critic commented on the symbolic effect of the 'columns of war' demarcating the performance area as follows: 'We people of the twentieth century have ethically not come a single step further; our lives more than ever are 
played out between these columns of war' ('Antigone' [1948] 1988). But in the same review the critic also notes that the archaic barbarism symbolises 'a bitter and undeniable truth: namely, the deep tragedy of humanity as a whole', the 'eternally true primordial law of humanity' (199f). As right as it is that Brecht was interested in the representation of human laws, it went against his intentions when these were seen as necessary. Nevertheless, a dialectical tension between antiquity/present and the performance (or with regard to the antiquity of our times, its barbarism), which Brecht was aiming for in his staging, was clearly not detected by reviewers. And this makes it necessary to reflect more deeply on the idea of an epic mode of representation, on Gestus, on techniques of creating a 'contradiction in the representation'. Brecht's call to 'expose the exposition' [das Zeigen zeigen] might direct our attention to the body in its mortality as the other of the rationalist construction of the fable, as a manifestation of 'what is repressed in the construction of a homogenous course of history' (Hamacher 2002, 174)-although this tendency was developed more explicitly in the stagings of tragedies after Brecht. In its consequences, such a tendency finally comes close to what Hölderlin meant when he wrote that the counter-rhythmic, tragic rupture would bring about the 'representation itself'.

\section{2) The Boundless Chorus (Schleef)}

Regarding the affinities between ancient tragedy and epic theatre, Brecht gave prominence to the messenger's report and the chorus. Nevertheless, the chorus can be considered as a repressed element in modern theatre. In Germany, the return of the chorus to the contemporary stage over the last two decades is closely linked with the theatre maker Einar Schleef (1944-2001). The director, set designer, painter and writer put on his first three productions at the Berliner Ensemble in East Berlin, and in this way was born into Brecht's legacy. However, when he was no longer able to continue his work, he left the German Democratic Republic and at the beginning of the 1980s resumed his activities at the Schauspiel Frankfurt. Schleef's central achievement is to have brought the historical form of the chorus into the present without adapting it to the aesthetic strategies of bourgeois theatre.

In 1986, Schleef created the work Die Mütter (The Mothers), in which he combined Euripides' The Suppliants and Aeschylus' Seven Against Thebes. This production is counted among the great theatre scandals of the twentieth century. Many viewers were appalled by what they perceived as the violence of the collective, and this entered their consciousness so strongly because Schleef avoided any kind of historicisation, and thereby strongly opposed the epic strategies of his predecessor Brecht. Schleef's theatre aims to reflect on the history of the collective in the theatre through a reference to tragedy.

In the second part of the project, Aeschylus' Seven Against Thebes, the chorus consists of a group of young women who fear being raped and enslaved by enemy soldiers. Schleef closes off the stage with the iron curtain, and for large parts of the performance the scenes are performed on a raised walkway running through the almost completely dark auditorium. 
Fourteen young women in red dresses and black military boots storm into the auditorium shouting and yelling, and squat on the steps of the walkway. Here, in the midst of the audience, with their bodies heaped together, they cry out about their fear of a possible siege. Occasionally, they organise themselves into a military formation and impulsively stretch out their arms in an attitude of attack. Their emphatic speech could be described as a staccato-like chanting, in unison and drilled. Later, they produce a

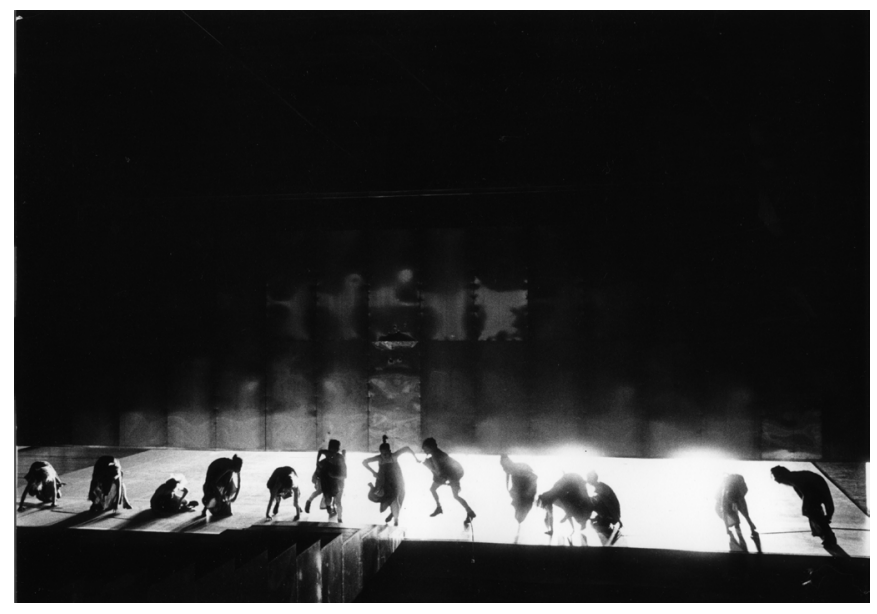

Figure 2. Photo: Claus Gretter loud clattering sound by hammering on the iron curtain. Towards the end of the performance, the chorus, now fifty strong, gathers on a platform behind the viewers-who may now feel surrounded-to produce a frenzy of speech and movement that could be felt throughout the auditorium.

Unlike the mass choruses in Max Reinhardt's stagings of classical drama, Schleef's chorus has a presence that is strongly characterized by moments of absence. On the one hand, the physicality of the chorus was emphasized by their running up and down the raised walkway close to the audience; on the other, the chorus subverted the power of the audience's gaze by performing in darkness or behind the audience, or huddling on the floor. In this way, the performance of the chorus avoided assuming a visual form and could not be fixed as an image. The particularly strong impact resulted from the fact that the chorus could not be classified as either historical or fictitious. Thus, the strangeness of the pathetic utterances could not be tied down to a specific source; the unleashed affect went beyond any link to the dramatic context or a specific group, and to some extent became an urgent concern for now and for everybody.

Perhaps the simplest response to this situation for many critics was an accusation of fascism. Many reviewers related the Dionysian energy of the chorus to the collective violence of history, which even led some to call for censorship (see 'Körperlich geschunden' 1986). Indeed, the production was withdrawn after only a few performances. And although it is possible to show in detail how these associations miss the point, they nevertheless bring to light an important dimension. The violence unleashed by Schleef's chorus exceeded the tragic form and thus challenged the concept of tragedy itself. Hegel understood tragedy as reconciliation in beautiful appearance. His emphasis on the containment of horror in the form can also be found in Schiller, who understood the chorus as a reflexive distancing from stimulating passions. Even Nietzsche's theory of tragedy, which rediscovered the Dionysian element, retains on a balanced economy of form-giving and formdestroying elements. Schleef's chorus theatre, however, breaks with every balance. His is a theatre of excess that dissolves illusionistic reality with a view to what is separated from it. In the staging of Die Mütter, the Apollonian form-giving element is 'unlocked', so that formally the acoustically produced affect is no longer sufficiently tied down. For this reason, Schleef's theatre is opposed to 
the idealistic view of tragedy as a successful act of overcoming. On closer inspection, it becomes clear that Schleef thereby also counters a social tendency that can be observed in Germany during the same period: to historicise and symbolically come to terms with the horror of the past and the fascist violence. Collective violence can be neither formally confined nor socially historicised. Instead, Schleef's theatre points towards a universal violence that is at the basis of every society, and which is only repressed through attempts at historicisation.

Nevertheless, it would be wrong to understand the perpetual cycle of violence as tragedy's sole message. Schleef's choruses also rise up against violence, suffering and victimhood. Despite the violence, the tone of the young women in Seven Against Thebes is also one of furious denunciationof their powerlessness and of male rule. Thus, at the end of the play, the chorus lines up facing the audience to discharge its fury in a deafening wall of noise. What is dominant here is less a lament resulting from their suffering than a wild denunciation, chanted collectively as an act of revolt. The act of overcoming is not carried out in the tragedy itself, but demanded for the present and the future.

Hence, the Dionysian pathos can also be perceived as a force of liberation. Nevertheless, in contrast to what was suggested by Nietzsche's theory in the nineteenth century, the Dionysian at the end of the twentieth century can no longer be described as an 'art-impulse of nature' (Kunsttrieb der Natur) or venerated as an authentic original force, but is deeply implicated in history. Schleef's tragic chorus refers to the ambivalent history of the emancipation of the collective in the twentieth century and represents a remarkable figure of inversion: the chorus-the collective force reflecting a community - cannot liberate itself without being subjected to its own violence. This circumstance can be grasped as a tragedy of revolt. Part of the provocation of the staging was that the forces of revolutionary liberation and violence could be understood as being interlinked. The particular interaction between revolt on the one hand, and the insight into what is supressed in every revolt on the other, constitutes the core theme of tragedy as caesura.

\section{3) The Tragic Void (Gotscheff)}

To finish, this ambivalence should be examined further in relation to the theatre of Dimiter Gotscheff (1943-2013). The work of the Bulgarian director can be seen as paradigmatic for the widespread topos that the stage is a place in which ghosts appear. Tragedy as a specific reflection on the threshold between times, on the standstill between the new and the old, takes place in this sense when in the theatre the dead speak. With this metaphor-which Gotscheff makes use of in close reference to Heiner Müller-the theatre is understood as a work of memory for history's victims. The return of the dead interrupts the continuous flow of history, reverses the arrow of time and thereby breaks open the closure of the present. History is thereby not represented, but put into question.

In ancient theatre, masks were used to allow 'the dead to speak', to create a present haunted by what is absent. Gotscheff did not use masks in a physical sense, but worked with a technique that could be called 'acoustic masks'. In various productions of ancient tragedies beginning in the 1980s-and mostly based on adaptations by Heiner Müller-Gotscheff developed a specific vocal 
style in which speech is shaped in such a way that it is not the individual speaker as such who is audible; rather, the speaker turns him- or herself into a medium for the text, which is thus exposed as an act of repetition and recurrence. In the 2006 production of Aeschylus' The Persians at the Deutsches Theater in Berlin, an actress dressed in a simple dark-coloured robe recites the text of the chorus in a translation by Heiner Müller. With great concentration, her voice navigates its

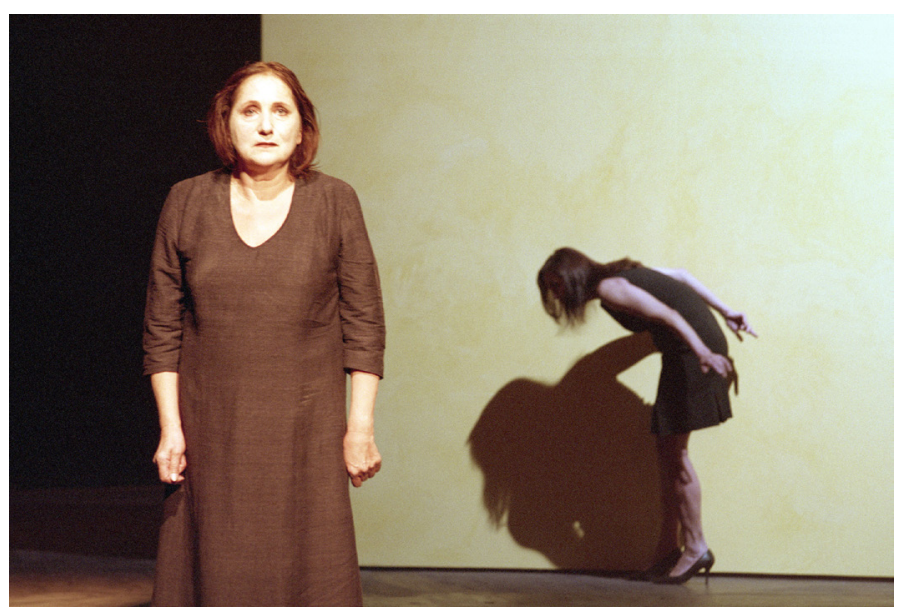
way through the dense and complex syntax. Soberly but carefully, she gives each word her full attention. Occasionally, by pausing a moment, she marks a distance to what is said.

Frequently, she appears to be reciting the text in order to better grasp what is said herself. In this spoken exploration of the historical material, the conventional linearity of speech is subverted, and time is slowed down. This gives rise to the curious sensation that an outside of the present is being indicated, which Derrida has called the 'non-contemporaneity with itself of the living present' (Derrida 1994, XVIII).

As with Brecht, one is made aware that something is emerging from the depths of time. However, the question of interruption is now posed in a new and different way. Gotscheff works with voices that seem to belong to no one, with tense, statue-like postures of the speaking bodies that seem to be in an intermediate state between living and dead, here and elsewhere, now and then-in short, with techniques of estrangement that Brecht himself had not developed so radically.

If we look at these elements of estrangement more closely, the concept of history in Gotscheff's epic theatre of tragedy becomes clear. Aeschylus' play The Persians describes the defeat of the Persian army in the Battle of Salamis. While at the beginning the chorus asks anxiously after the whereabouts of their country's sons, a messenger brings news of the terrible defeat. At the end of the play, the tragic hero Xerxes appears, whose recklessness had brought about the disaster. Still with a tie but shirtless, the actor Samuel Finzi

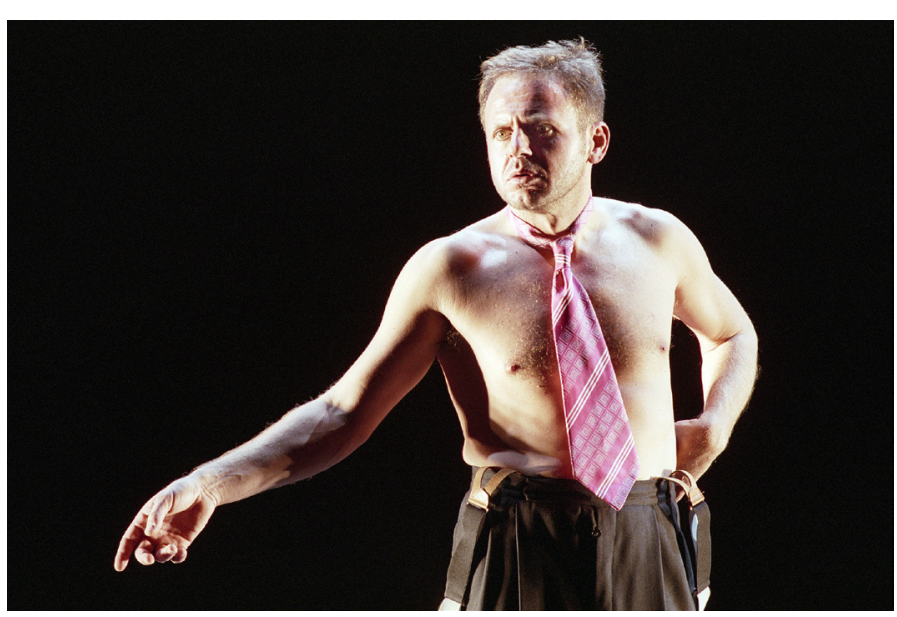

Figure 4: Photo: Iko Freese 
stands alone on the empty stage. He silently faces the audience. Finzi/Xerxes treats the stray sentences as if he were asking himself what this language might be good for. The body is staged in its helplessness; in the struggle with language, body and language become separated from one another.

In such moments, the tragic failure of the protagonist is obvious. Man's limitations become apparent, his lack of sovereignty over himself and history (cf. Müller-Schöll 2010). It becomes clear how strongly chance penetrates every occurrence and how uncontrollable history is, how history encompasses what men make, but also what makes men, or 'what perverts the sense of their actions, and devours those that considered themselves the authors' (Rancière 2006, 71).

If nothing were added to this interpretation, Gotscheff's staging might be misunderstood as being deeply pessimistic. And it is certainly true that in the literature on Gotscheff's theatre there is a widespread view that Gotscheff was only interested in describing perpetual failure as the eternal recurrence of the same (cf. Detchewa 2008, 138). However, there are also other interpretations on offer to grasp the concept of the tragic here. If at the end of the tragedy one finds an exhausted and defeated man, a victim of his own hubris, this man is also a perpetrator appearing before the tribunal of the audience. The protagonist is exposed as a tyrant whose rule is at an end, and to whom the chorus refuses allegiance.

But what does it mean for the interpretation if Xerxes appears both as perpetrator and victim, if the suffering of the fallen man is presented as much as the criticism of a ruler? If opposing aspects are juxtaposed in the staging, this results in a kind of Benjaminian standstill. It is in this way that Gotscheff's theatre reveals itself, such that the fullness of perspectives simultaneously brings about an emptying. One might think of Heiner Müller's Letter to the Director, in which he writes: 'Tragedy is left empty-handed. Its path rejects the consolation that is a deferral. It transports nothingness, the possible beginning' (Müller 2005, 267). This idea of tragedy as the opening up of an emptiness, a nothingness, is related to Hölderlin's understanding of tragedy in which 'the tragic transport is actually empty', since 'very soon there does not appear the change of representation but the representation itself' (Hölderlin 1988b, 102): that is, the caesura.

In this sense, Gotscheff's staging of The Persians can be understood as an endgame. It aims to bring the eternal recurrence of the same to an end, whereby drama and history are dismantled into their component parts. For Foucault, the sens historique strives to undermine everything that appears necessary and unchangeable; it 'places within a process of development everything considered immortal in man' (Foucault 1984, 87). Foucault understands this historical sense as a question of the physiology of history. Hence, Gotscheff's The Persians should be understood as a recourse to such a sens historique - to the actor-bodies that withdraw from embodiment and make other uses of their bodies thinkable; to the material of language that disintegrates during the process of articulation and can thus be heard differently; to the time in which history can take place.

These considerations on Brecht's failed historicisation, Schleef's tragedy of the collective, and Gotscheff's ghostly emptiness of tragedy have developed aspects of a theatre of caesura. The examples can be distinguished from practices of Vergegenwärtigung (making-present) above all 
through what Maurice Blanchot, Jean-Luc Nancy and others have called désoeuvrement ('unworking' or inoperativity), which means that no closed formal solutions are manifested. Paradoxically, one can only do justice to the work when it is not set to work. In this sense, Hölderlin and Benjamin both conceive of tragedy as an incisive event that undermines the established order, but without, however, arriving at a new one. When Benjamin draws on Franz Rosenzweig's conception of silence in tragedy, he points to a force of contradiction that does not have a language at its disposal in which it could articulate itself. Similarly, in his Antigonemodell, Brecht stresses that the study of this book should be directed primarily towards the experiment and the attempt (Brecht 1968, vol. 25, 81). The historical thought resulting from the encounter with ancient Greek tragedy can be understood in this sense as one of the central conditions for the critical function of the theatre since the 1960s. At the same time, the theatre of caesura brings to light what is overlooked when the horizons of past and present are fused: for Schleef the collective force; for Gotscheff the actorbodies that withdraw from embodiment, and the material of disintegrated language.

\section{Translated by Benjamin Carter}

\section{Notes}

\footnotetext{
1 The productions have been collected by the Archive of the Performance of Greek and Roman Drama at Oxford University: http://www.apgrd.ox.ac.uk/research-collections/performance-database/productions (accessed 20 August 2016); another databank is being compiled as part of the European Network of Research and Documentation of Performances of Ancient Greek Drama (Arc-Net). See also Flashar 1991, 225ff.

2 On the close link between the discourse on myth and the adaptation of classics, see chapter 1 of my dissertation, Dreyer (2014), 47ff.

${ }^{3}$ On the discourse on the unstageability of ancient tragedy, see Boetius 2005, 14-18; Flashar 1991, 61ff.

${ }^{4}$ It leads to the singular and particular, as Samuel Weber $(2016 ; 2004,97-120)$ has shown, to the 'lebendigen Sinn, der nicht berechnet werden kann' (Hölderlin 1999b, 259).
}

\section{Works Cited}

'Antigone.' (1948) 1988. Neue Bündner Zeitung, 18 February 1948. Reproduced in Brechts Antigone des Sophokles, edited by Werner Hecht, 195. Frankfurt am Main: Suhrkamp.

Benjamin, Walter. (1940) 2003. 'On the concept of history.' In Walter Benjamin, Selected Writings, Volume 4: 1938 1940. Edited by Marcus Bullock and Michael W. Jennings, 389-400. Cambridge, Mass. and London: Harvard University Press.

2003. Selected Writings, Volume 4: 1938-1940. Edited by Marcus Bullock and Michael W. Jennings. Cambridge, Mass. and London: Harvard University Press. 
. 1996. Walter Benjamin: Selected Writings, Volume 1: 1913-1926. Edited by Marcus Bullock and Michael W. Jennings. Cambridge MA and London: Harvard University Press.

Boetius, Susanne. 2005. Die Wiedergeburt der griechischen Tragödie auf der Bühne des 19. Jahrhunderts. Tübingen: Niemeyer. https://doi.org/10.1515/9783110945058

Brecht, Bertolt. 1992. Werke. Große kommentierte Berliner und Frankfurter Ausgabe. Edited by Werner Hecht et al. 30 vols. Frankfurt am Main: Suhrkamp.

. 1968. Gesammelte Werke. Edited in cooperation with Elisabeth Hauptmann. 20 vols. Frankfurt am Main: Suhrkamp.

Derrida, Jacques. 1994. Specters of Marx. The State of the Debt, the Work of Mourning and the New International. Translated by Peggy Kamuf. London and New York: Routledge.

Detchewa, Violeta. 2008. 'Kurzschluss. Versuch über Gotscheffs Theater am Beispiel von Koltès' “Kampf des Negers und der Hunde" und Aischylos' "Die Perser".' In Das Schweigen des Theaters - Der Regisseur Dimiter Gotscheff, edited by Peter Staatsmann and Bettina Schültke, 129-138. Berlin: Vorwerk.

Dreyer, Matthias. 2014. Theater der Zäsur. Antike Tragödie im Theater seit den 1960er Jahren. Paderborn: Wilhelm Fink.

Fischer-Lichte, Erika. 1998. 'Berliner Antikenprojekte. 150 Jahre Theatergeschichte.' In Berliner Theater im 20. Jahrhundert, edited by Erika Fischer-Lichte, 111-140. Berlin: Fannei und Walz.

Flashar, Hellmut. 1991. Inszenierung der Antike. Das griechische Drama auf der Bühne der Neuzeit 1585-1990. Munich: Beck.

Foley, Helene P. 1999. 'Modern Performance and Adaptations of Greek Tragedy.' Transactions of the American Philological Association 129:1-12. https://doi.org/10.2307/284422

Foucault, Michel. 1984. 'Nietzsche, Genealogy, History.' In The Foucault Reader, edited by Paul Rabinow, 76-100. London: Penguin.

Gadamer, Hans-Georg. (1960) 2006. Truth and Method. Translated by Joel Weinsheimer and Donald G. Marshall. London and New York: continuum.

Hall, Edith, and Fiona Macintosh, eds. 2005. Greek tragedy and the British theatre, 1660-1914. Oxford: Oxford University Press.

Hamacher, Werner. 2002. "Jetzt". Benjamin zur historischen Zeit.' In Benjamin Studies 1. Perception and Experience in Modernity, edited by edited by Helga Geyer-Ryan, Paul Koopman, and Klaas Yntema, 145-183. Amsterdam and New York: Rodopi. https://doi.org/10.1163/9789004334168009

Hölderlin, Friedrich. (1804) 1999a. 'Anmerkungen zum Ödipus.' In Friedrich Hölderlin, Sämtliche Werke. Historischkritische Ausgabe, vol. 16, edited by D. E. Sattler, 247-258. Frankfurt am Main: Stroemfeld.

___. (1804) 1999b. 'Anmerkungen zum Antigonae.' In Friedrich Hölderlin, Sämtliche Werke. Historisch-kritische Ausgabe, vol. 16, edited by D. E. Sattler, 247-258. Frankfurt am Main: Stroemfeld.

. (1804) 1988a. 'Remarks on Oedipus.' In Friedrich Hölderlin, Essays and Letters on Theory. Translated by Thomas Pfau, 101-108. Albany: State University of New York Press.

. (1804) 1988b. 'Remarks on Antigone.' In Friedrich Hölderlin, Essays and Letters on Theory. Translated by Thomas Pfau, 109-116. Albany: State University of New York Press.

Horkheimer, Max, and Theodor W. Adorno. (1944) 2002. Dialectic of Enlightenment. Philosophical Fragments. Stanford: Stanford University Press.

'Körperlich geschunden.' 1986. Der Spiegel, 3 March, 54.

Lemke, Anja. 2002. Konstellation ohne Sterne. Zur poetischen und geschichtlichen Zäsur bei Martin Heidegger und Paul Celan. Munich: Wilhelm Fink.

Macintosh, Fiona, et al., eds. 2005. Agamemnon in Performance, 458 BC to AD 2004. Oxford: Oxford University Press. 
Müller, Heiner. 2005. Werke, vol. 8, edited by Frank Hörnigk. Frankfurt am Main: Suhrkamp,

Müller-Schöll, Nikolaus. 2010. "'unter Undenkbarem wandelnd...". Ödipus von Sophokles nach Hölderlin von Müller im Raum von Mark Lammert inszeniert von Dimiter Gotscheff am Hamburger Thalia Theater.' In Lücken sehen... Beiträge zu Theater, Literatur und Performance. Festschrift Hans-Thies Lehmann zum 66sten, edited by Martina Groß and Patrick Primavesi, 165-178. Heidelberg: Winter Universitätsverlag.

Rancière, Jacques. 2006. 'Die Geschichtlichkeit des Films.' In Kunst, Fortschritt, Geschichte, edited by Christoph Menke and Juliane Rebentisch, 69-86. Berlin: Kadmos.

Reinhardt, Max. (1901) 1974. 'Über ein Theater, wie es mir vorschwebt.' In Max Reinhardt, Schriften. Briefe, Reden, Aufsätze, Interviews, Gespräche, Auszüge aus Regiebüchern, edited by Hugo Fetting, 64-67. Berlin: Henschel.

Stenzel, Julia. 2009. 'Der Zuschauer im Bild der Antike. Konstruktionen des 19. Jahrhunderts.' Forum Modernes Theater 1: 3-17.

Weber, Samuel. 2016. 'Zäsur als Unterbindung. Einige vorläufige Bemerkungen zu Hölderlins "Anmerkungen".' In Rhythmos. Formen des Unbeständigen nach Hölderlin, edited by Jörn Etzold and Moritz Hannemann, 39-62. Paderborn: Wilhelm Fink.

2004. Theatricality as Medium. New York: Fordham University Press. https://doi.org/10.5422/fso/9780823224159.001.0001

\section{Biography}

Matthias Dreyer is an assistant professor/postdoctoral research associate at the Institute for Theatre, Film and Media Studies, Goethe-University in Frankfurt am Main. Academic studies in Vienna, Paris, Baltimore and Berlin; work as a dramaturge; 2005-2011 research associate at the Institute of Theatre Studies, FU Berlin and the Research Centre "Transformations of Antiquity"; 2011 doctor's degree; recent research focus on collectivity, biopolitics and the history of liveness. Most important publication: Theater der Zäsur. Antike Tragödie im Theater seit den 1960er Jahren (2014).

(c) 2017 Matthias Dreyer

cc) () (9) Except where otherwise noted, this work is licensed under a Creative Commons Attribution-

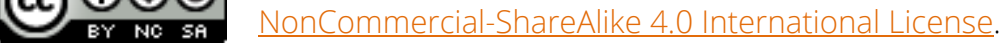

